\title{
Phytochemical Composition and Biological Activities of Wild Scolymus maculatus L.
}

\author{
Saleh Abu-Lafi ${ }^{1, \dagger}$, Mahmoud Rayan ${ }^{2,+}$, Mahmud Masalha ${ }^{2}$, Basheer Abu-Farich ${ }^{2,+}$, \\ Hashem Al-Jaas ${ }^{3}$, Malek Abu-Lafi ${ }^{4}$ and Anwar Rayan ${ }^{2,5, *}$ \\ 1 Faculty of Pharmacy, Al-Quds University, Abu-Dies 144, Palestine; sabulafi@staff.alquds.edu \\ 2 QRC-Qasemi Research Center, Al-Qasemi Academic College, Baka El-Ghrabiah 30100, Israel; \\ mahmoud_ryan@hotmail.com (M.R.); mahmudmasalha@gmail.com (M.M.); af_basheer@qsm.ac.il (B.A.-F.) \\ 3 Central Public Health Laboratory, Ministry of Health, Ramallah 4284, Palestine; hashem_222@yahoo.com \\ 4 Faculty of Medicine, Al-Quds University, Abu-Dies 144, Palestine; Malek.al.1991@gmail.com \\ 5 Drug Discovery Informatics Lab, the Institute of Applied Research - Galilee Society, Shefa-Amr 20200, Israel \\ * Correspondence: a_rayan@qsm.ac.il \\ + These authors contributed equally to this work.
}

Received: 21 March 2019; Accepted: 27 April 2019; Published: 30 April 2019

\begin{abstract}
Background: The wild population of spotted golden thistle, Scolymus maculatus, which belongs to the Compositae family, is believed to be one of the multi-curative wild plants mentioned in Flora Palaestina. This study aims to disclose the phytochemical composition, antioxidant potential, and antimicrobial activity of wild S. maculatus collected from the farms of Kabul, a village in northwest Galilee, for the first time. Methods: The phytochemical components of crude S. maculatus extracts from methanol, ethyl acetate, and $n$-hexane solvents were separated and identified using gas chromatography-mass spectrometry (GC-MS) in the electron impact (EI) mode. The free radical scavenging of the plant extracts was measured by DPPH assay. The microdilution test was used to determine the minimum inhibitory concentrations (MICs) of different $S$. maculatus extracts and to evaluate their antimicrobial activities. Results: Thirty-two phytochemicals were found in S. maculatus extracts including stigmasterol, $\gamma$-sitosterol, lupeol, lupeol acetate, and $\beta$-amyrin. Phytochemicals, such as 2-linoleoylglycerol, $\gamma$-sitosterol, $\beta$-amyrin, lupeol, $(3 \alpha)$-12-oleanen-3-yl acetate, and lupenyl acetate, were found to dominate the methanol extract. Most of these compounds were also observed in ethyl acetate and $n$-hexane extracts, but at different levels, in addition to some other minor compounds. The various extracts were investigated for their antioxidant and antimicrobial activity. The ethanolic and the methanolic extracts were shown to exhibit the highest free radical scavenging by DPPH assay with a half-maximally effective concentration $\left(\mathrm{EC}_{50}\right)$ of 0.37 and $0.65 \mathrm{mg} / \mathrm{mL}$ respectively, while the other three extracts (aqueous, ethyl acetate and $n$-hexane) were less active and their $\mathrm{EC}_{50}$ (effective concentration at which DPPH radical was scavenged by $50 \%$ ) were above $1.0 \mathrm{mg} / \mathrm{mL}$. Moreover, MICs were determined to be effective against Staphylococcus aureus, Salmonella typhimurium, and Candida albicans microorganisms. Ethyl acetate and the ethanolic extracts are active against the three types of microorganisms at a minimum inhibitory concentration (MIC) of $0.5 \mathrm{mg} / \mathrm{mL}$, while aqueous and the $n$-hexane extracts are inactive against Salmonella typhimurium. Conclusions: The results show that $S$. maculatus extracts are a rich source of compounds that can play an important role in human health, and in a broader context, in the treatment of various diseases, such antimicrobial and antioxidant-related ailments.
\end{abstract}

Keywords: Scolymus maculatus; phytochemicals; GC-MS analysis; herbal medicine; free radical scavenging; antioxidant; antimicrobial; DPPH assay 


\section{Introduction}

Plant-based nutrients and natural products have long been considered to be linked with human health and even evidenced to reduce risks of chronic human illnesses, such as inflammation [1-3], diabetes [4], cancer [5,6], and microbial-related diseases [7-11]. To date, herbal medicine is widely practiced in Palestine [12]. Well-reputed, it plays an integral part in the cultural heritage and public healthcare practices of the region. A paucity of herbal products used in folk medicine has been scientifically investigated and recorded $[13,14]$. The efficacy, safety, toxicity, dosage, and the usage instructions for medicinal plants are generally transmitted verbally from one generation to another [14]. One of the putative multi-curative wild herbal plants of Flora Palaestina is the spotted golden thistle, S. maculatus (Compositae family). This wild plant is very common in the Mediterranean region [15]. Its shape is very similar to the famous milk thistle plant, Silybum marianum (L.), which is used to protect the liver. S. marianum's main active ingredients are silybin, silydianin, and silychristine, collectively known as silymarin [15]. S. maculatus, however, is also believed to contain other useful phytochemicals that may prevent and treat diseases, such as liver disease, cancer, and diabetes. Moreover, a stem decoction is traditionally prepared to treat intestinal and kidney inflammation [15]. In light of this, wild S. maculatus phytochemicals from methanol, ethyl acetate, and $n$-hexane solvents were investigated using gas chromatography-mass spectrometry (GC-MS) in the electron impact (EI) mode to identify authentic principal compounds. Thirty-two phytochemicals were detected for the first time in S. maculatus. Moreover, in vitro antioxidant activities were tested using DPPH assay. MICs were determined for effectiveness against Staphylococcus aureus (S. aureus), Salmonella typhimurium, and Candida albicans microorganisms.

\section{Materials and Methods}

\subsection{Plant Collection and Extract Preparation}

Whole S. maculatus plants, comprising stems and flowers, were collected from the farms of the village of Kabul in the northwest of Galilee during October 2014. The plant was identified and authenticated by Dr. Khaled Sawalha, a botanist from the Biology Department of Al-Quds University. The specimens were washed with distilled water and dried in the shade for three weeks. Two hundred milliliters each of water, methanol, ethanol, ethyl acetate, and $n$-hexane were added separately to the dried ground plant material $(20 \mathrm{~g})$ in a beaker, and all the samples were sonicated for $60 \mathrm{~min}$ at $45^{\circ} \mathrm{C}$, then left in a dark glass bottle for $24 \mathrm{~h}$ for complete extraction. The extracts were filtered by passing the solvents through a $0.2 \mu \mathrm{m}$ filter. Ten milliliters were taken from the extracts for GC-MS tests. The solvent remaining from each extract was evaporated with a rotary vacuum evaporator under reduced pressure. The yields of the extracts $(w / w \%)$ were $3.3 \%, 3.7 \%, 2.4 \%, 7.9 \%$, and $2.3 \%$ for aqueous, methanolic, ethanolic, ethyl acetate, and $n$-hexane, respectively. The crude extracts were dissolved in DMSO to prepare stock solutions with a $16.0 \mathrm{mg} / \mathrm{mL}$ concentration, then subjected to free radical scavenging tests using DPPH assay. Microdilution tests were conducted to determine MICs of the extracts against Staphylococcus aureus, Salmonella typhimurium, and Candida albicans microorganisms. The chemical compositions of the three extracts were verified by GC-MS.

\subsection{Instrumentation}

The extracts were analyzed using a Perkin Elmer, Clarus gas chromatograph connected to a Clarus 600 C mass spectrometer (GC-MSPerkinElmer, Inc, Shelton, CT, USA). The GC-MS was operated in the electron impact ionization mode (EI) at $70 \mathrm{eV}$. A Perkin Elmer autosampler was used with $2 \mathrm{~mL}$ vials. The capillary GC column (DB-5 MS, Agilent Technologies, Inc, Santa Clara, CA, USA) was equipped with fused silica that consisted of $5 \%$ diphenyl polysiloxane and $95 \%$ dimethyl polysiloxane, $28 \mathrm{~m} \times 0.25 \mathrm{~mm}$, with a coating film thickness of $0.25 \mu \mathrm{m}$ (Restek Corporation, Bellefonte, PA, USA). 


\subsection{GC-MS Chromatographic Condition}

The flow rate of the carrier gas was $1 \mathrm{~mL} \mathrm{He} / \mathrm{min}$. The injector temperature was set at $235^{\circ} \mathrm{C}$, the source temperature at $250{ }^{\circ} \mathrm{C}$, and the interface temperature at $260{ }^{\circ} \mathrm{C}$. A split ratio of $1: 20$ was adopted during the entire analysis. The column gradient temperature was held at $50{ }^{\circ} \mathrm{C}$ for two minutes, then raised from $50{ }^{\circ} \mathrm{C}$ to $180{ }^{\circ} \mathrm{C}$ at a ramp rate of $5^{\circ} \mathrm{C} / \mathrm{min}$ and from $180{ }^{\circ} \mathrm{C}$ to $280{ }^{\circ} \mathrm{C}$ at a ramp rate of $15^{\circ} \mathrm{C} / \mathrm{min}$ and held there for an extra five minutes. A solvent cut time of $4.5 \mathrm{~min}$ was used to eliminate the solvent's gigantic peak. The mass range was from 50 up to $480 \mathrm{Da}$, with a scan interval of 0.2 seconds. The identification of compounds was mainly based on matching their MS spectra with those of NIST mass spectral library.

\subsection{Free Radical Scavenging Capabilities of Extracts}

The free radical scavenging of different concentrations of the $S$. maculatus plant extracts was measured by DPPH assay [16]. One-milliliter portions of the plant extract were added to one-milliliter ethanolic DPPH solution (with a concentration of $100 \mathrm{ppm}$ ). The assay was performed using two-fold serial dilution by DMSO, starting from the stock solution of the plant extract. The mixture was shaken strongly and allowed to stand for $30 \mathrm{~min}$ at room temperature in a dark place. The absorbance of the solution was measured at $517 \mathrm{~nm}$ and converted into a percentage of free radical scavenging (FRS\%) using the following equation:

$$
\text { FRS } \left.\%=100 \times\left\{1-\left[\left(\mathrm{A}_{\text {sample }}-\mathrm{A}_{\text {blank }}\right)\right) /\left(\mathrm{A}_{\text {control }}-\mathrm{A}_{\text {blank }}\right)\right]\right\}
$$

where, $A_{\text {sample }}$ is the absorbance of the mixture (plant extract and DPPH), $A_{\text {blank }}$ is the absorbance of the plant extract solution, and $\mathrm{A}_{\text {control }}$ is the absorbance of the ethanolic solution of DPPH.

Free radical scavenging at each concentration was repeated four times, and the data were expressed as the average \pm the standard error of the means of the four experiments. Gallic acid was used as a positive control. The scavenging potential of the gallic acid and the various extracts was evaluated by the DPPH assay test and was expressed in terms of half-maximal effective concentration $\left(\mathrm{EC}_{50}\right)$, where $\mathrm{EC}_{50}$ is defined as the concentration that causes a decrease in the initial DPPH concentration by $50 \%$. The $\mathrm{EC}_{50}$ value was determined by extracting the equation for the linear part of the graph and substituting $50 \%$ for the $y$ value, while calculating the concentration value of the $x$-axis.

\subsection{Antibacterial and Antifungal Activity}

Microdilution tests were used to determine the MICs of the different samples. The broth microdilution assay was performed using twofold serial dilution in brain heart infusion (BHI) broth. The test was carried out in 96-well flat-bottomed microtitration plates. The cell suspension was prepared in BHI broth with an optical density equivalent to 0.5 of the McFarland standards, and diluted 1:100 in BHI broth to obtain a final concentration of $5 \times 10^{5}$ colony-forming units per milliliter $(\mathrm{CFU} / \mathrm{mL})$. Controls with broth only and broth with bacteria without any of the antibacterial agents were also included in each plat. One hundred $\mu \mathrm{l}$ of the antibacterial agent were put in the first microplate well and serially diluted in $\mathrm{BHI}$ broth. One hundred $\mu \mathrm{l}$, corresponding to $5 \times 10^{5} \mathrm{CFU} / \mathrm{mL}$, were added to all the wells. The plates were incubated at $37^{\circ} \mathrm{C}$ for $18 \mathrm{~h}$ overnight. Erythromycin was used as a positive control for $S$. aureus, while nystatin was used as a positive control for Candida albicans and Tetracycline for Salmonella typhimurium strain LT2. The minimum inhibitory concentration (MIC) was defined as the lowest concentration able to inhibit the visible growth of bacteria in triplicate wells. After the MIC was visually determined, twenty microliters of $p$-iodonitrotetrazolium violet $(8 \mathrm{mg} / \mathrm{mL} \mathrm{EtOH})$ were added to each well. The plate was incubated for another $30 \mathrm{~min}$ and assessed visually for any change in color from yellow to pink, which would indicate the reduction of dye due to bacterial growth. 


\subsection{Statistical Analysis}

Statistical analyses were performed using Excel spreadsheet software (v16.0, Microsoft, Redmond, WA, USA). All experiments were conducted in quadruplicate, and the data were expressed as an average \pm standard deviation. A $p$-value (calculated by $t$-test) of less than 0.05 was considered statistically significant.

\section{Results and Discussion}

In this study, the phytochemical composition of wild S. maculatus methanol, ethyl acetate and $n$-hexane crude extracts was revealed. GC-MS screening in the electron impact mode (EI) revealed about 32 compounds for the first time. A satisfactory resolution and elution time were obtained on the capillary GC DB-5 column used (Figure 1). Of the 32 compounds seen in Table 1 and Figure 2, stigmasterol, $\gamma$-sitosterol, lupeol, lupeol acetate, and $\alpha$-amyrin are known to exhibit important pharmacological activity, in particular anticancer, anti-inflammatory, and antibacterial activity [17-19]. Phytochemicals, such as 2-linoleoylglycerol (5.87\%), $\gamma$-sitosterol (5.73\%), $\beta$-amyrin (15.98\%), lupeol $(22.25 \%),(3 \alpha)-12-o l e a n e n-3-y l$ acetate $(9.14 \%)$, and lupenyl acetate $(18.11 \%$,) dominated the methanol extract (see Table 1 and Figures 1 and 2). Almost all of these compounds were observed in ethyl acetate and $n$-hexane extracts, but in different proportions.

Table 1. Phytochemical percentages and retention times for wild S. maculatus extracts of methanol, ethyl acetate, and $n$-hexane, identified by gas chromatography-mass spectrometry (GC-MS).

\begin{tabular}{|c|c|c|c|c|c|}
\hline \multicolumn{4}{|c|}{ Phytochemical Names and Retention Times } & \multicolumn{2}{|c|}{ Area \% } \\
\hline No. & Compound Name & RT (min) & Methanol & Ethyl Acetate & $n$-Hexane \\
\hline 1 & 1-Ethylbutyl hydroperoxide & 9.054 & & & 6.42 \\
\hline 2 & 1-Ethyl-2-heptylcyclopropane & 16.29 & & 0.32 & \\
\hline 3 & Acetoglyceride & 18.09 & & 1.19 & \\
\hline 4 & 2,4-Decadienal & 20.303 & & & 1.78 \\
\hline 5 & Nonylcyclopropane & 21.89 & & 0.63 & \\
\hline 6 & (E)-3-Octadecene & 26.88 & & 0.59 & \\
\hline 7 & Coniferyl alcohol & 30.64 & 0.37 & & \\
\hline 8 & 6,10,14-Trimethyl-2-pentadecanone & 32.36 & 0.24 & 0.40 & \\
\hline 9 & Ethyl palmitate & 35.36 & & & 0.99 \\
\hline 10 & Methyl linoleate & 37.27 & 0.97 & & \\
\hline 11 & 14-Octadecenoic acid, methyl ester & 37.38 & 0.30 & 0.24 & \\
\hline 12 & Ethyl linolelaidate & 38.455 & & & 12.48 \\
\hline 13 & Ethyl (9E)-9-octadecenoate & 38.554 & & & 2.35 \\
\hline 14 & Palmitamide & 39.00 & & 42.67 & 11.97 \\
\hline 15 & Doconexent & 40.08 & 0.69 & & 2.61 \\
\hline 16 & Oleamide & 42.04 & & 5.08 & 2.90 \\
\hline 17 & Octyl cyclohexanecarboxylate & 42.44 & & 1.27 & 0.74 \\
\hline 18 & Tetracosane & 44.4 & 2.15 & 0.28 & \\
\hline 19 & Diploptene & 45.16 & & & 15.68 \\
\hline 20 & 2-Linoleoylglycerol & 47.08 & 5.87 & 1.46 & 0.39 \\
\hline 21 & Spinacene & 48.49 & & 0.47 & 0.32 \\
\hline 22 & Tetratriacontane & 49.68 & 2.34 & & 1.01 \\
\hline 23 & Unknown & 54.23 & 2.04 & & \\
\hline 24 & Stigmasterol & 57.64 & 2.55 & & 0.27 \\
\hline 25 & $\gamma$-Sitosterol & 59.58 & 5.73 & 0.22 & 1.59 \\
\hline 26 & $\beta$-Amyrin & 61.19 & 15.98 & 0.61 & 5.44 \\
\hline 27 & Stigmasterol acetate & 61.33 & & 1.27 & \\
\hline 28 & Lupeol & 63.04 & 22.25 & & 10.05 \\
\hline 29 & Stigmastan-3,5-diene & 63.76 & & 4.21 & \\
\hline 30 & $(3 \alpha)$-12-Oleanen-3-yl acetate & 64.23 & 9.14 & 12.11 & 4.22 \\
\hline 31 & Lupenyl acetate & 66.47 & 18.11 & 26.82 & 11.03 \\
\hline 32 & Unknown & 67.33 & 11.26 & 0.16 & 7.78 \\
\hline
\end{tabular}




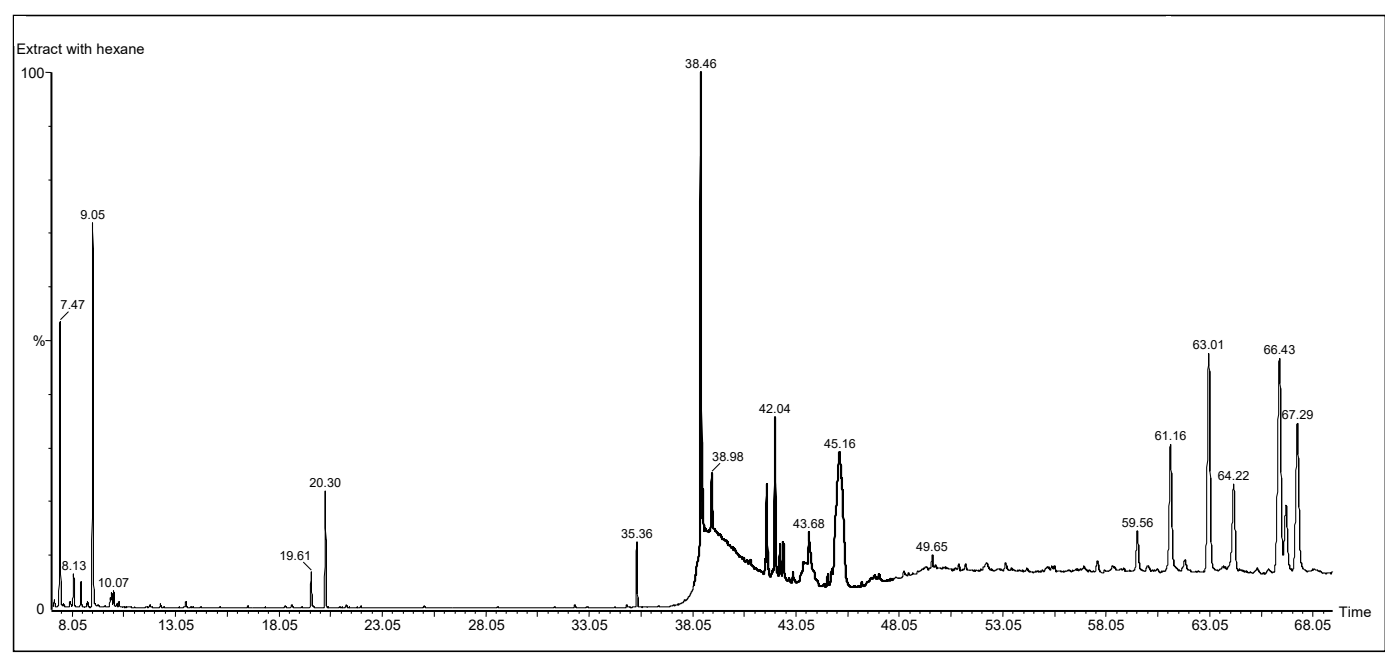

(a)

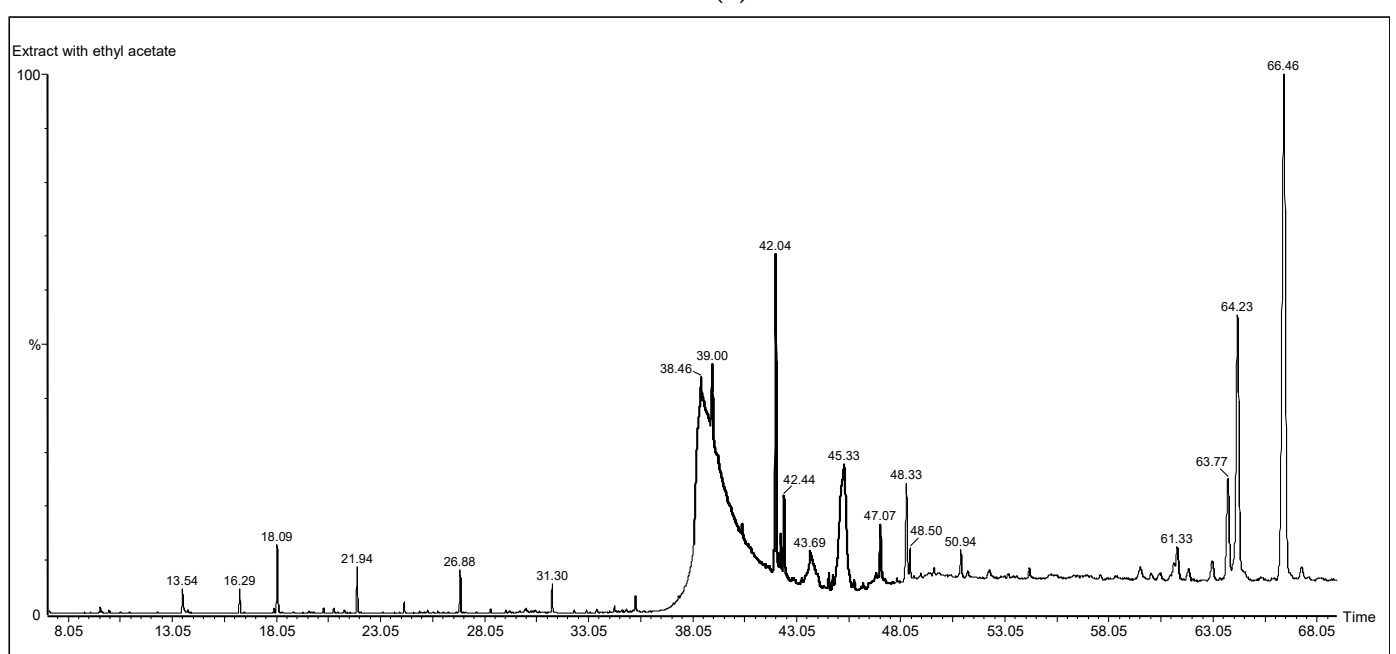

(b)

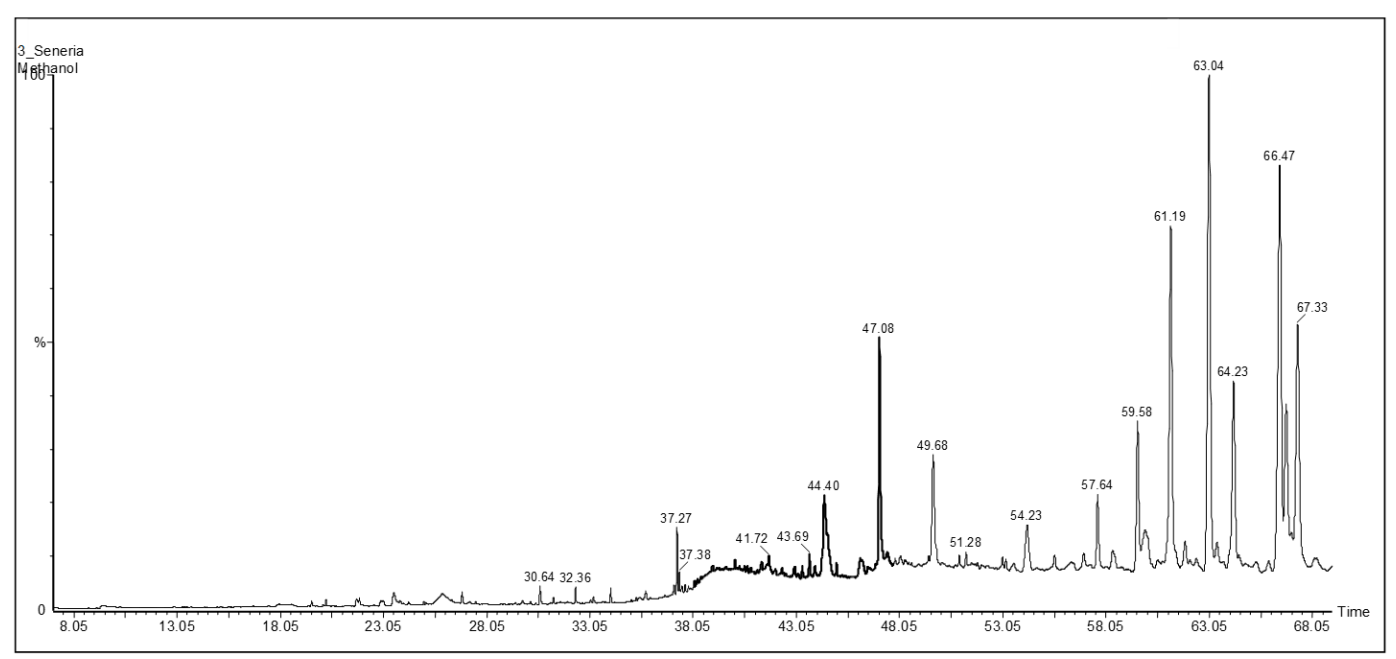

(c)

Figure 1. Typical GC-MS total ion chromatograms (TICs) of wild Scolymus maculatus extracts from $n$-hexane (a), ethyl acetate (b), and methanol (c). 
<smiles>CC[C@H](/C=C/[C@@H](C)[C@H]1CC[C@H]2[C@@H]3CC=C4C[C@@H](O)CC[C@]4(C)[C@H]3CC[C@@]21C)C(C)C</smiles>

Stigmasterol<smiles></smiles>

$\gamma$-Sitosterol

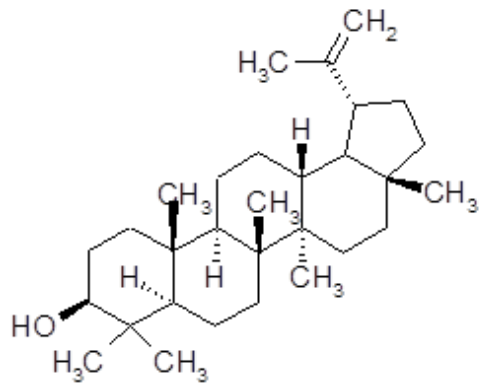

Lupeol

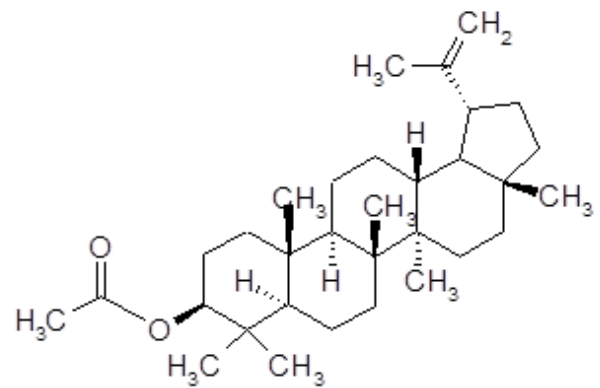

Lupeol acetate

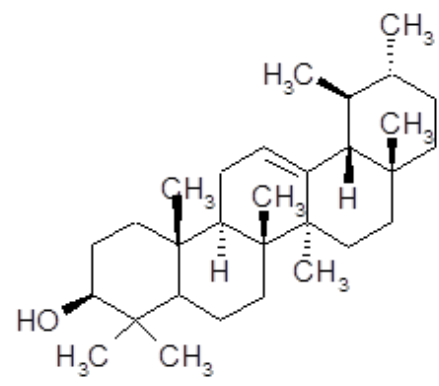

$\beta-$ Amyrin

Figure 2. Phytochemicals stigmasterol, $\gamma$-sitosterol, lupeol, lupeol acetate, and beta-amyrin present in wild Scolymus maculatus extracts of methanol, ethyl acetate, and $n$-hexane, identified by GC-MS.

It is worth noting that sitosterol has been reported to possess antibacterial potential [20]. Stigmasterol exhibits antibacterial activity against methicillin-resistant Staphylococcus aureus [16] and has been reported as well to significantly inhibit tumor promotion in two-stage carcinogenesis in mice [21]. A mixture of sitosterol and stigmasterol has been shown to possess anti-inflammatory activity after topical application [22]. Therefore, it is expected that the presence of such sterols in S. maculatus would be of paramount importance for combating and curing diseases.

Lupeol (Figure 2), another significant phytochemical in S. maculatus, is about $22 \%$ in the identified peaks in the methanol extract. Numerous preclinical animal studies suggest that lupeol has potential as anti-inflammatory, anti-microbial, anti-protozoal, anti-proliferative, anti-invasive, anti-angiogenic and cholesterol-lowering agent [23]. $\beta$-amyrin (Table 1 and Figure 2), which was found in the methanol and $n$-hexane extract in about $16 \%$ and $5.44 \%$, respectively, were reported recently to have significant anticancer activity [24], and a recent study highlights the potential of both lupeol and stigmasterol as new, promising anti-MRSA (methicillin-resistant Staphylococcus aureus) agents [16]. $\beta$-amyrin from 
L. microcladia natural product has shown potential antibacterial activity [25]. The authors suggest intensifying the study on L. microcladia as a source of $\beta$-amyrin. Moreover, among the three molecules that were isolated from $S$. globulifera, lupeol and $\beta$-amyrin exhibit potential as new anti-Enterococcus compounds [26]. Growth inhibition of Streptococcus from the oral cavity by $\alpha$-and $\beta$-amyrin terpenoids and $\alpha$-amyrin esters have also been reported [27]. Table 1 shows the presence of $\alpha, \beta$-unsaturated aliphatic aldehydes, such as 2,4-decadienal. Recent studies also demonstrate the capability of such a compound to combat bacterial growth [28,29].

The antioxidant reacts with the stable free radical DPPH and converts it to 1, 1-diphenyl-2-picryl hydrazine. The ability to scavenge the free radical DPPH was measured at an absorbing wavelength of $517 \mathrm{~nm}$. All the extracts of S. maculatus were tested for their free radical scavenging activity. The EC50 values of the five extracts are shown in Table 2 and Figure 3. The ethanolic extract is the most active (probably containing a higher concentration of antioxidants) while the $n$-hexane extract is the least active one.

Table 2. The half-maximal effective concentration $\left(\mathrm{EC}_{50}\right)$ values of the radical scavenging activity of five S. maculatus extracts: aqueous, methanolic, ethanolic, ethyl acetate, and $n$-hexane $(n=4)$.

\begin{tabular}{cc}
\hline S. maculatus Extract Type & EC $_{\mathbf{5 0}}(\mathbf{m g} / \mathbf{m L})$ \\
\hline Aqueous extract & 1.27 \\
Methanolic extract & 0.65 \\
Ethanolic extract & 0.37 \\
Ethyl acetate extract & 1.08 \\
n-hexane extract & $>2.0$ \\
\hline
\end{tabular}

Antibacterial activity was anticipated because of the presence of compounds, such as lupeol, amyrin, sitosterol, and stigmasterol, which have shown potential antibacterial potential [20,25,30]. Therefore, the aqueous, methanol, ethanol, ethyl acetate, and $n$-hexane extracts of wild S. maculatus were evaluated in comparison to tetracycline, erythromycin and nystatin positive controls. The aqueous extract was deliberately used to imitate the usual method of plant decoction. The MICs against Staphylococcus aureus, Salmonella typhimurium, and Candida albicans microorganisms were determined. The ethyl acetate and the ethanolic extracts were active against the three types of microorganisms, with a MIC of $0.5 \mathrm{mg} / \mathrm{mL}$, while the aqueous and the $n$-hexane extracts were inactive against Salmonella typhimurium (Table 3). The methanolic extract was active against Staphylococcus aureus and Candida albicans but not against Salmonella typhimurium.

Table 3. The minimum inhibitory concentrations (MICs) of five S. maculatus extracts (aqueous, methanolic, ethanolic, ethyl acetate, and $n$-hexane) against Staphylococcus aureus, Salmonella typhimurium, and Candida albicans microorganisms.

\begin{tabular}{cccc}
\hline $\begin{array}{c}\text { Type of } \\
\text { Extract/Microbial Strain }\end{array}$ & $\begin{array}{c}\text { Staphylococcus } \\
\text { aureus }\end{array}$ & $\begin{array}{c}\text { Salmonella } \\
\text { typhimurium }\end{array}$ & $\begin{array}{c}\text { Candida } \\
\text { albicans }\end{array}$ \\
\hline Aqueous extract & $0.5 \mathrm{mg} / \mathrm{mL}$ & $>4.0 \mathrm{mg} / \mathrm{mL}$ & $1.0 \mathrm{mg} / \mathrm{mL}$ \\
Methanolic extract & $0.5 \mathrm{mg} / \mathrm{mL}$ & $>4.0 \mathrm{mg} / \mathrm{mL}$ & $0.5 \mathrm{mg} / \mathrm{mL}$ \\
Ethanolic extract & $0.5 \mathrm{mg} / \mathrm{mL}$ & $0.5 \mathrm{mg} / \mathrm{mL}$ & $0.5 \mathrm{mg} / \mathrm{mL}$ \\
Ethyl acetate extract & $0.5 \mathrm{mg} / \mathrm{mL}$ & $0.5 \mathrm{mg} / \mathrm{mL}$ & $0.5 \mathrm{mg} / \mathrm{mL}$ \\
$n$-hexane extract & $1.0 \mathrm{mg} / \mathrm{mL}$ & $>4.0 \mathrm{mg} / \mathrm{mL}$ & $0.5 \mathrm{mg} / \mathrm{mL}$ \\
Tetracycline & - & $0.01 \mathrm{mg} / \mathrm{mL}$ & - \\
Erythromycin & $0.0078 \mathrm{mg} / \mathrm{mL}$ & - & - \\
Nystatin & - & - & $0.00312 \mathrm{mg} / \mathrm{mL}$ \\
\hline
\end{tabular}



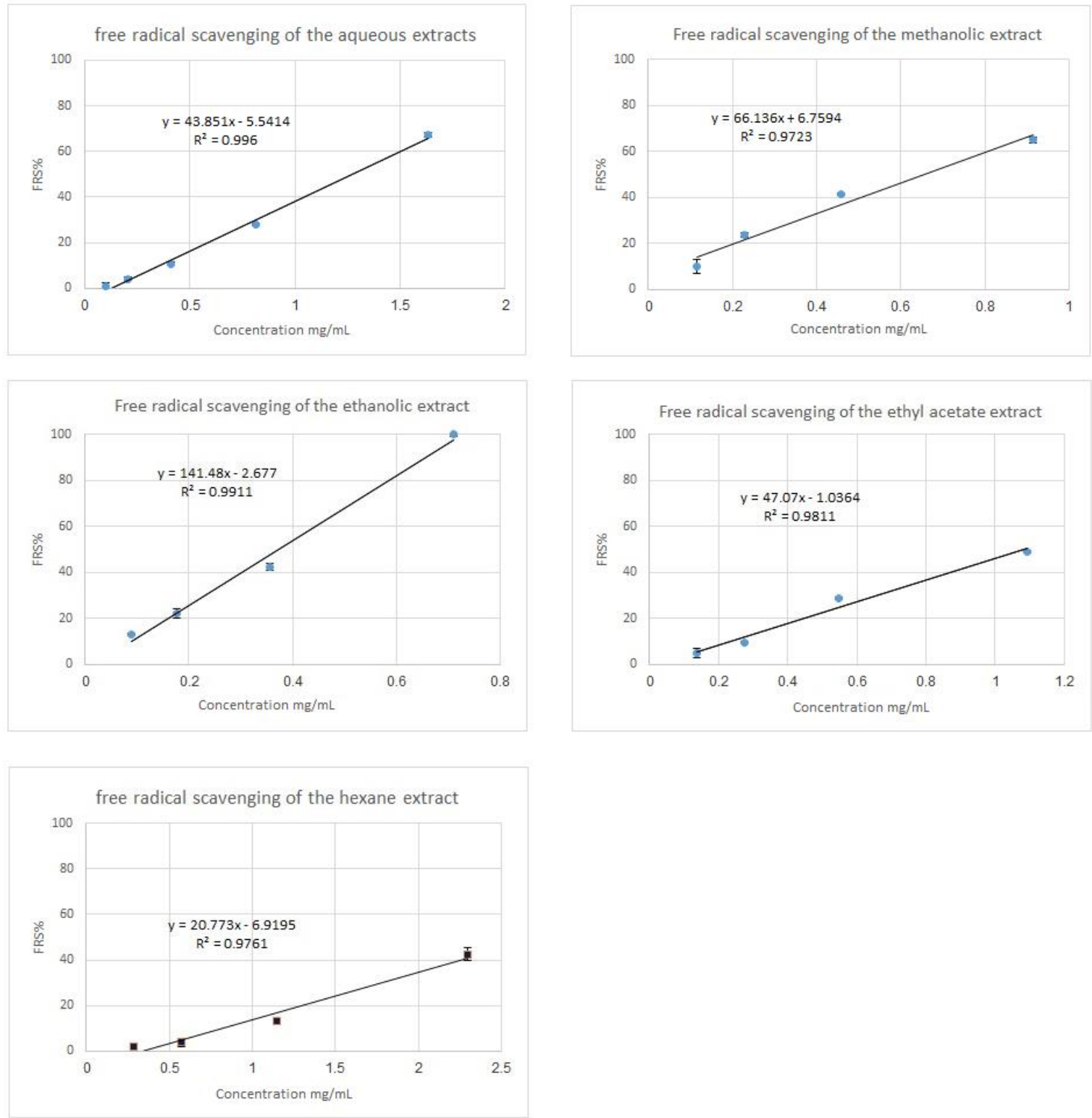

Figure 3. Free radical scavenging of all S. maculatus five extracts. At each concentration, the experiment was run four times. The data shown are the means \pm the standard error of the means from the four experiments.

\section{Conclusions}

Thirty-two volatile components were detected in wild S. maculatus for the first time. Lupeol was the predominant component, with a percentage exceeding $22 \%$ in methanol. Lupeol acetate was the principle phytochemical in the ethyl acetate extract $(26 \%)$ and to a lesser extent $(11 \%)$ in $n$-hexane. Stigmasterol, $\gamma$-sitosterol, lupeol, lupeol acetate, and $\beta$-amyrin, which are reported here for the first time as phytochemical components in S. maculatus, are biologically active compounds according to scientific literature and most likely responsible for some of the activities of wild S. maculatus. Isolation of all antioxidant and antimicrobial chemicals from the most active extracts and testing their contribution to the biological activities of wild $S$. maculatus and potential synergism is recommended. The findings disclosed herein are important and may suggest the importance of consuming S. maculatus as food. Enriched extracts could be prepared that possess certain activity beneficial to human health, and in a broader context, that could be useful for the treatment of various diseases. As well, S. maculatus could 
be a source of promising lead compounds for the development of new treatments for microbial-related diseases and some other diseases.

Author Contributions: All seven authors contributed extensively to the work presented in this paper. Conceptualization, A.R. and S.A.-L.; methodology, M.R., B.A.-F., and M.M.; validation, H.A.-J., M.M., and B.A.-F.; formal analysis, M.A.-L.; investigation, M.M. and H.A.-J.; resources, S.A.-L. and A.R.; writing-original draft preparation, S.A.-L., M.R., and M.A.-L; writing-review \& editing, A.R.; project administration, A.R.; funding acquisition, A.R. and S.A.-L.

Funding: Al-Qasemi Research and Development Authority as well as the Ministry of Science, Technology and Space.

Acknowledgments: We would like to thank the Central Public Health Laboratory in Ramallah for facilitating the use of the GC-MS instrument.

Conflicts of Interest: The authors declare no conflict of interest.

\section{Abbreviations}

$\begin{array}{ll}\text { DPPH } & \text { diphenylpicrylhydrazyl } \\ \text { AA } & \text { antioxidant activity } \\ \text { MIC } & \text { minimum inhibitory concentration } \\ \text { GC-MS } & \text { gas chromatography-mass spectrometry } \\ \text { EI } & \text { electron impact } \\ \text { BHI } & \text { brain heart infusion } \\ \text { EC } 50 & \text { half-maximal effective concentration } \\ \text { TIC } & \text { total ion chromatogram }\end{array}$

\section{References}

1. Aswad, M.; Rayan, M.; Abu-Lafi, S.; Falah, M.; Raiyn, J.; Abdallah, Z. Nature is the best source of anti-inflammatory drugs: Indexing natural products for their anti-inflammatory bioactivity. Inflamm. Res. 2018, 67, 67-75. [CrossRef] [PubMed]

2. Frank, A.; Abu-Lafi, S.; Adawi, A.; Schwed, J.S.; Stark, H.; Rayan, A. From medicinal plant extracts to defined chemical compounds targeting the histamine $\mathrm{H} 4$ receptor: Curcuma longa in the treatment of inflammation. Inflamm. Res. 2017, 66, 923-929. [CrossRef]

3. Zaid, H.; Raiyn, J.; Osman, M.; Falah, M.; Srouji, S.; Rayan, A. In silico modeling techniques for predicting the tertiary structure of human H4 receptor. Front. Biosci. 2016, 21, 597-619.

4. Zeidan, M.; Rayan, M.; Zeidan, N.; Falah, M.; Rayan, A. Indexing natural products for their potential anti-diabetic activity: Filtering and mapping discriminative physicochemical properties. Molecules 2017, 22, 1563. [CrossRef]

5. Chikara, S.; Nagaprashantha, L.D.; Singhal, J.; Horne, D.; Awasthi, S.; Singhal, S.S. Oxidative stress and dietary phytochemicals: Role in cancer chemoprevention and treatment. Cancer Lett. 2018, 413, 122-134. [CrossRef] [PubMed]

6. Rayan, A.; Raiyn, J.; Falah, M. Nature is the best source of anticancer drugs: Indexing natural products for their anticancer bioactivity. PLoS ONE 2017, 12, e0187925. [CrossRef]

7. Kacergius, T.; Abu-Lafi, S.; Kirkliauskiene, A.; Kirkliauskiene, A.; Gabe, V.; Adawi, A.; Rayan, M.; Qutob, M.; Stukas, R.; Utkus, A.; et al. Inhibitory capacity of Rhus coriaria L. extract and its major component methyl gallate on Streptococcus mutans biofilm formation by optical profilometry: Potential applications for oral health. Mol. Med. Rep. 2017, 16, 949-956. [CrossRef] [PubMed]

8. Gabe, V.; Kacergius, T.; Abu-Lafi, S.; Kalesinskas, P.; Masalha, M.; Falah, M.; Abu-Farich, B.; Melninkaitis, A.; Zeidan, M.; Rayan, A. Inhibitory Effects of Ethyl Gallate on Streptococcus mutans Biofilm Formation by Optical Profilometry and Gene Expression Analysis. Molecules 2019, 24, 529. [CrossRef] [PubMed]

9. Masalha, M.; Abu-Lafi, S.; Abu-Farich, B.; Rayan, M.; Issa, N.; Zeidan, M.; Rayan, A. A New Approach for Indexing Honey for Its Heath/Medicinal Benefits: Visualization of the Concept by Indexing Based on Antioxidant and Antibacterial Activities. Medicines 2018, 5, 135. [CrossRef] [PubMed] 
10. Masalha, M.; Rayan, M.; Adawi, A.; Abdallah, Z.; Rayan, A. Capturing antibacterial natural products with in silico techniques. Mol. Med. Rep. 2018, 18, 763-770. [CrossRef]

11. Rayan, M.; Abdallah, Z.; Abu-Lafi, S.; Masalha, M.; Rayan, A. Indexing natural products for their antifungal activity by filters-based approach: Disclosure of discriminative properties. Curr. Comput. Aided Drug Des. 2018, 15, 235-242. [CrossRef] [PubMed]

12. Abu-Lafi, S.; Makhamra, S.; Rayan, I.; Barriah, W.; Nasser, A.; Abu Farkh, B.; Rayan, A. Sesamin from Cuscuta palaestina natural plant extracts: Directions for new prospective applications. PLoS ONE 2018, 13, e0195707. [CrossRef] [PubMed]

13. Said, O.; Khalil, K.; Fulder, S.; Azaizeh, H. Ethnopharmacological survey of medicinal herbs in Israel, the Golan Heights and the West Bank region. J. Ethnopharmacol. 2002, 83, 251-265. [CrossRef]

14. Sawalha, A.F.; Sweileh, W.M.; Zyoud, S.H.; Jabi, S.W. Self-therapy practices among university students in Palestine: Focus on herbal remedies. Complement. Ther. Med. 2008, 16, 343-349. [CrossRef] [PubMed]

15. Azaizeh, H.; Saad, B.; Khalil, K.; Said, O. The state of the art of traditional arab herbal medicine in the eastern region of the mediterranean: A review. Evid. Based Complement. Alternat. Med. 2006, 3, 229-235. [CrossRef]

16. Adnan, S.N.; Ibrahim, N.; Yaacob, W.A. Transcriptome analysis of methicillin-resistant Staphylococcus aureus in response to stigmasterol and lupeol. J. Glob. Antimicrob. Resist. 2017, 8, 48-54. [CrossRef] [PubMed]

17. Asadi-Samani, M.; Rafieian-Kopaei, M.; Azimi, N. Gundelia: A systematic review of medicinal and molecular perspective. Pak. J. Biol. Sci. 2013, 16, 1238-1247.

18. Raicht, R.F.; Cohen, B.I.; Fazzini, E.P.; Sarwal, A.N.; Takahashi, M. Protective effect of plant sterols against chemically induced colon tumors in rats. Cancer Res. 1980, 40, 403-405.

19. Yasukawa, K.; Takido, M.; Matsumoto, T.; Takeuchi, M.; Nakagawa, S. Sterol and triterpene derivatives from plants inhibit the effects of a tumor promoter, and sitosterol and betulinic acid inhibit tumor formation in mouse skin two-stage carcinogenesis. Oncology 1991, 48, 72-76. [CrossRef]

20. Ododo, M.M.; Choudhury, M.K.; Dekebo, A.H. Structure elucidation of beta-sitosterol with antibacterial activity from the root bark of Malva parviflora. SpringerPlus 2016, 5, 1210. [CrossRef]

21. Ali, H.; Dixit, S.; Ali, D.; Alqahtani, S.M.; Alkahtani, S.; Alarifi, S. Isolation and evaluation of anticancer efficacy of stigmasterol in a mouse model of DMBA-induced skin carcinoma. Drug Des. Dev. Ther. 2015, 9, 2793-2800. [CrossRef] [PubMed]

22. Gomez, M.A.; Saenz, M.T.; Garcia, M.D.; Fernandez, M.A. Study of the topical anti-inflammatory activity of Achillea ageratum on chronic and acute inflammation models. Z. Naturforsch. C 1999, 54, 937-941. [CrossRef] [PubMed]

23. Saleem, M.; Murtaza, I.; Tarapore, R.S.; Suh, Y.; Adhami, V.M.; Johnson, J.J.; Siddiqui, I.A.; Khan, N.; Asim, M.; Hafeez, B.B.; et al. Lupeol inhibits proliferation of human prostate cancer cells by targeting beta-catenin signaling. Carcinogenesis 2009, 30, 808-817. [CrossRef]

24. Lopez-Lazaro, M.; Palma De La Pena, N.; Pastor, N.; Martín-Cordero, C.; Navarro, E.; Cortés, F.; Ayuso, M.J.; Toro, M.V. Anti-tumour activity of Digitalis purpurea L. subsp. heywoodii. Planta. Med. 2003, 69, 701-704. [PubMed]

25. Abdel-Raouf, N.; Al-Enazi, N.M.; Al-Homaidan, A.A.; Ibraheem, I.B.M.; Al-Othman, M.R.; Hatamleh, A.A. Antibacterial $\beta$-amyrin isolated from Laurencia microcladia. Arab. J. Chem. 2015, 8, 32-37. [CrossRef]

26. De Castilho, A.L.; da Silva, J.P.C.; Saraceni, C.H.C.; Collantes Díaz, I.E.; Paciencia, M.L.B.; Varella, A.D.; Suffredini, I.B. In vitro activity of Amazon plant extracts against Enterococcus faecalis. Braz. J. Microbiol. 2014, 45, 769-779. [CrossRef] [PubMed]

27. Diaz-Ruiz, G.; Hernandez-Vazquez, L.; Luna, H.; Wacher-Rodarte, M.D.C.; Navarro-Ocana, A. Growth inhibition of Streptococcus from the oral cavity by alpha-amyrin esters. Molecules 2012, 17, 12603-12611. [CrossRef]

28. Bisignano, G.; Lagana, M.G.; Trombetta, D.; Arena, S.; Nostro, A.; Uccella, N.; Mazzanti, G.; Saija, A. In vitro antibacterial activity of some aliphatic aldehydes from Olea europaea L. FEMS Microbiol. Lett. 2001, 198, 9-13. [CrossRef] 
29. Trombetta, D.; Saija, A.; Bisignano, G.; Arena, S.; Caruso, S.; Uccella, G.; Uccella, N.; Castelli, F. Study on the mechanisms of the antibacterial action of some plant alpha, beta-unsaturated aldehydes. Lett. Appl. Microbiol. 2002, 35, 285-290. [CrossRef]

30. Wal, A.; Srivastava, R.S.; Wal, P.; Rai, A.; Sharma, S. Lupeol as a magical drug. Pharm. Biol. Eval. 2015, 2, 142-151.

(C) (1)

(C) 2019 by the authors. Licensee MDPI, Basel, Switzerland. This article is an open access article distributed under the terms and conditions of the Creative Commons Attribution (CC BY) license (http://creativecommons.org/licenses/by/4.0/). 